\title{
The Application of Maqasid Al-Shari'ah in the Foreign Policy of Islamic States
}

\author{
Usman Safiyanu Duguri, Mohd Afandi Salleh, Isyaku Hassan, Mohd Nazri \\ Latiff Azmi
}

To Link this Article: http://dx.doi.org/10.6007/IJARBSS/v11-i3/8559

DOI:10.6007/IJARBSS/v11-i3/8559

Received: 21 January 2021, Revised: 16 February 2021, Accepted: 28 February 2021

Published Online: 10 March 2021

In-Text Citation: (Duguri et al., 2021)

To Cite this Article: Duguri, U. S., Salleh, M. A., Hassan, I., \& Azmi, M. N. L. (2021). The Application of Maqasid Al-Shari' ah in the Foreign Policy of Islamic States. International Journal of Academic Research in Business and Social Sciences, 11(3), 88-96.

\section{Copyright: (c) 2021 The Author(s)}

Published by Human Resource Management Academic Research Society (www.hrmars.com)

This article is published under the Creative Commons Attribution (CC BY 4.0) license. Anyone may reproduce, distribute, translate and create derivative works of this article (for both commercial and non-commercial purposes), subject to full attribution to the original publication and authors. The full terms of this license may be seen

at: http://creativecommons.org/licences/by/4.0/legalcode

Vol. 11, No. 3, 2021, Pg. 88 - 96

Full Terms \& Conditions of access and use can be found at http://hrmars.com/index.php/pages/detail/publication-ethics 


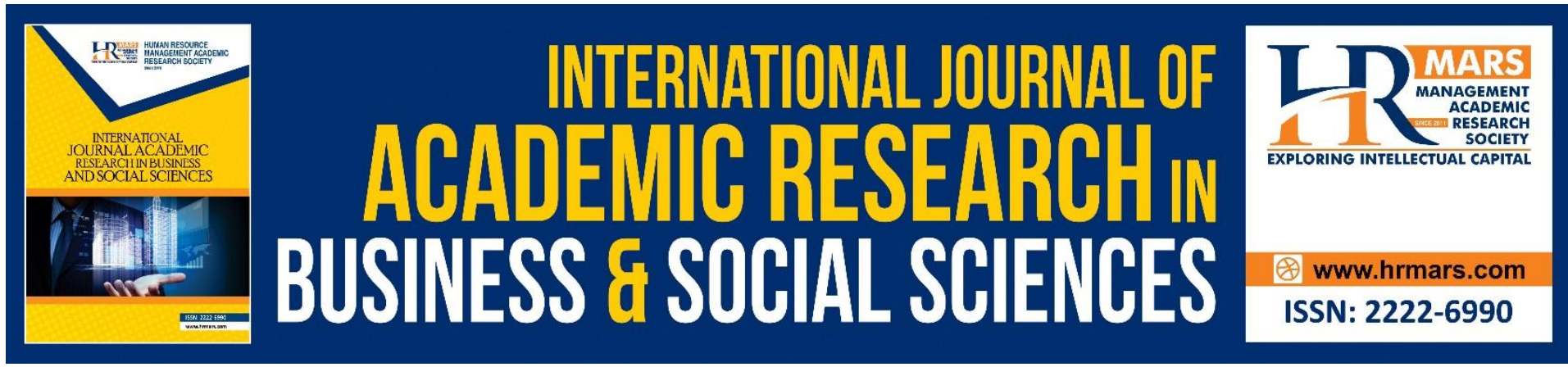

\title{
The Application of Maqasid Al-Shari'ah in the Foreign Policy of Islamic States
}

\author{
Usman Safiyanu Duguri, Mohd Afandi Salleh \\ Faculty of Law and International Relations, Universiti Sultan Zainal Abidin \\ Gong Badak Campus, 21300 Kuala Nerus, Terengganu, Malaysia \\ Email: usmansufyanduguri@yahoo.com, afandisalleh@gmail.com \\ Isyaku Hassan \\ Faculty of Languages and Communication, Universiti Sultan Zainal Abidin \\ Gong Badak Campus, 21300 Kuala Nerus, Terengganu, Malaysia \\ Email: isyaku87@gmail.com \\ Mohd Nazri Latiff Azmi \\ Faculty of Languages and Communication, Universiti Sultan Zainal Abidin \\ Gong Badak Campus, 21300 Kuala Nerus, Terengganu, Malaysia \\ Email:mohdnazri@unisza.edu.my
}

\begin{abstract}
Religion is crucial in the foreign policy formulation of Islamic states. Islamic law can play an important role in foreign policy formulation as Maqasid Al-Shariah (Objectives of Islamic Law) are universal. Maqasid Al-Shariah is divided into three categories: general Maqasid, specific Maqasid, and partial Maqasid. Despite this universality, there is an inadequate explanation of the application of Maqasid Al-Shariah in foreign policy. Therefore, this study aims to explore the application of Maqasid Al-Shariah in the foreign policy of Islamic states. The study employed a qualitative approach in which document analysis was used to gather information from the United Nations Human Rights report of 2015. The study found that Maqasid AlShariah can play a significant role in the foreign policy of Islamic states through the protection of people's life, property, health, religion, and dignity. Further analysis revealed that Maqasid Al-Shariah can be successfully incorporated in the foreign policy-making process of Islamic states, particularly where international treaties neglect or contradict the principles of Islamic law. Hence, Maqasid Al-Shariah should be fully implemented in the foreign policy process of governments of Islamic countries at both the national and international levels.

Keywords: Foreign Policy, Maqasid Al-Shariah, Islamic Countries, International Treaty, Policy Formulation
\end{abstract}




\section{Introduction}

The role of religion as a component molding states of mind towards foreign policy has been given little consideration by researchers. Researchers have focused on the role of religion in domestic governmental issues, particularly in discretionary conduct (Laldin, 2014; Witro, 2020). Maqasid Al-Shariah (Objectives of Islamic law) can play a crucial role in the foreign policy of Islamic states due to its universality. There are five Maqasid (objectives) of Shariah: Protection of life, protection of property, protection of health, protection of religion, and protection of dignity. These objectives are generally classified into three categories, general Maqasid, specific Maqasid, and partial Maqasid. Maqasid Al-Shariah incorporates issues related to community, nations, and humanity in general (Yudha, Ryandono, Rijal, \& Wijayanti, 2020). Shariah is a universal legal systes that regulates the affairs of Muslim societies (Mohd, Yunus, Hassan, 2020).

The objectives of Shariah are essential in protecting people's integrity and can be a very beneficial parameter for policy formulation and foreign relations. They can be very useful for the government in dealing with international matters. Governments, especially those that uphold Islamic values can utilize Maqasid Al-Shariah to formulate foreign policy. The relationship between Islamic states and the international community is necessary. Therefore, the role of Maqasid Al-Shariah in Islamic countries is to protect people's life, property, health, religion, and dignity. However, there is an inadequate explanation of the role of Maqasid AlShariah in foreign policy (Mandaville, \& Hamid, 2018; Salleh, Mohamed, Yusob, \& Yazid, 2016; Warner, \& Walker, 2011). Therefore, this study aims to explore how Maqasid Al-Shariah can be applied in the foreign policy of Islamic states.

The study employed a qualitative approach in which document analysis to explore the role of Maqasid Al-Shariah in the foreign policy of Islamic states. This is because document analysis allows researchers to obtain detailed and reliable information that is relevant to the topic under study (Bowen, 2009). The United Nations Human Rights report of 2015 entitled "Core International Human Rights Treaties" was considered in this study. Other secondary sources of data include religious books and empirical papers.

\section{Foreign Policy Making Process and Treaty Making Process}

Foreign policy concerns the state, meaning, it is state-driven (Tarasofsky, 2002; Wicaksana, 2019). Like local policy, foreign policy is set and defined inside the state, yet it is proposed for and executed in an "environment external to that state" (Thomas \& Klare, 1989). According to Thomas and Klare, foreign policy is an area of politics that bridges all the important boundaries between the nation-state and its international environment. From one perspective, foreign policy is viewed as a clear arrangement of activities set to secure a nation's particular external objectives (Gindarsah, 2012; Ahmed, 2019). It comprises rules for a state concerning its external activities or particular international issues of concern (Hall \& Soskice, 2003). Again, foreign policy is seen as a progression of routine reactions by a state to issues or occasions that occur in the global environment (Hill, 2003). This context reflects two activities of foreign policy. First, there is the conception that it is identified with state activism. Second, the idea that the perspectives approach is a significantly organized response to the external environment (Thomas \& Klare, 1989).

A study showed that foreign policy cannot be isolated from the domestic context where it is created (Anceschi, 2010). According to Anceschi, there would be no foreign policy without domestic society and the state. This contention does not put on a show to nullify the realist observation that worldwide legislative issues cannot be isolated from the global framework. 
The foreign policy ought not to be related to a game like chess a single dominant value, and unitary. Putnam (1988) explains that the system is concerned with a more practical approach. Putnam proposes a two-level diversion approach where the legislature addresses governmental issues at two levels: domestic and international.

Moreover, the legitimate establishment of foreign relations in Islam depends on Shariah. The first primary sources of Shariah are the Quran and the Sunnah (Prophetic traditions). The Figh (Islamic jurisprudence) is obtained from Shariah, which covers the heap of issues throughout man's life (Johnston, 2002; Rani, Fikri, \& Mahfud, 2020). Among the fundamental issues, which contemporary Islamic jurisprudence endeavors to manage, are those related to foreign relations. Muslim law specialists have conducted different assessments to reform the standard of foreign relations based on Islamic law (Hall \& Soskice, 2003; Johnston, 2002). People who were affected by the practical approach of an Islamic state may trust that foreign relations in Islam rely upon the attitudes of non-Muslims toward Islam and Muslims. They may think that the premise of foreign relations of an Islamic state is a fight, yet under specific conditions. In contrast, jurists argue that the origin of foreign relations in Islam is peace, because the Quran unambiguously states "there is no compulsion in religion." (Quran 2: 256) Accordingly, the principles of war advocated by traditionalists are not compatible with this unrelenting Quranic rule (Fisol, Radzi, \& Othman, 2017).

Treaties are one of the methods through which states relate to each other. As global law has moved from building bi-sidelong to multi-horizontal connections, bargains have turned out to be progressively critical. Treaties act to clear up and enhance principles of international law by interpreting composed understandings and advancing the coordination of uniform state conducts in a variety of areas (Al-Rodiman, 2013). The term "treaty" has regularly been used as a generic term embracing all instruments binding at international law concluded between international entities, regardless of their formal designation (Kohona, 2002). A treaty is defined as "an international agreement concluded between States in written form and governed by international law, whether embodied in a single instrument or two or more related instruments and whatever its particular designation" (United Nations, 1969, p. 133). This definition includes treaties related to international agreements involving international organizations as parties.

To speak of a "treaty" in the generic sense, an instrument has to meet various criteria. First, it has to be a binding instrument, which means that the contracting parties intend to create legal rights and duties. Second, the instrument must be concluded by states or international organizations with treaty-making power. Third, it has to be governed by international law. Finally, the engagement has to be in writing. Even before the 1969 Vienna Convention on the Law of Treaties (United Nations, 1969), the word "treaty" in its generic sense had been generally reserved for engagements concluded in written form.

From the definitions above, a treaty refers to a part of international law. However, countries often go into a treaty thinking that they are withdrawing from the standard run, yet it does not mean that the general rule of international law has changed. For instance, an article of a settlement may discuss the general control of international law while another article may explain an exemption to the rules (Al-Rodiman, 2013). In Islam, for Mu'ahadah (treaty) to be legitimate, the agreement of the two parties must be communicated. In this regard, Allah says: "O you who believe! Eat not up your property among yourselves unjustly except it be a trade amongst you, by mutual consent." (Quran 4: 29). This verse explains the reason for the rule of the common assent of both parties. Also, this rule applies to all agreements, including those related to exchanges or complementary arrangements (Dusuki, 
2009). The Prophet's tradition demonstrates that there is no deal without common assent as a transfer of the wealth of a Muslim is not lawful without his consent. This rule is extended to include the assent of both parties (Dusuki \& Bouheraoua, 2011).

If assent is essential concerning the exchange and other related contracts, then it is considerably more vital in international treaties that are principally associated with the Islamic state. Moreover, if the assent is one of the essential rules of concluding contracts, including settlements, nonattendance of assent due to inadequacies (such as compulsion or blunder) does not block the thought process to conclude a treaty, but rather it harms the agreement or legally binding part of the bargain. The condition for soundness of the agreement is assent (Meyerhof, 1948). In any case, the legitimacy of treaties depends to a large extent on how they are completed. A legitimate arrangement ought to satisfy essential components and conditions in the process of a treaty. These components and conditions fall into four fundamental classifications: basic elements, conditions, process, and reservations (Karczewska \& Magdalena, 2015).

\section{The Role of Maqasid Al-Shari'ah in Foreign Policy Formulation}

The purpose of this study relates to how Maqasid Al-Shariah contributes to foreign policy formulation in the Islamic States. This is because no country is self-sufficient, which makes international relations necessary amongst states in a contemporary world of globalization (Ahmad, 2019; Cerny, 1996; Nadler \& Saguy, 2004; Wicaksana, 2019). In this regard, Islamic countries generally have their own political and socio-economic interests, which determines the formulation of their foreign policy, particularly related to international treaties. However, Maqasid Al-Shariah may widen the scope of policy-making in Islamic countries, making it possible for them to implement foreign policies based on principles of Islamic law.

Maqasid Al-Shariah can be a vital aspect of foreign policy in Islamic countries as it contributes to the protection of people's wealth, health, dignity, and religion (Salleh et al., 2016). The fundamentals of Shariah generally focus on the well-being of both individuals and the community because Islamic law is designed to protect those benefits and to facilitate the improvement of people's quality of life (Kamali, 1998, Rani et al., 2020). Maqasid Al-Shariah aims to protect religion, life, intellect, lineage, and property. Additionally, these objectives are categorized under Maqasid Al-Dhoruriyyah (essentials objectives) (Dusuki \& Abozaid, 2007; Yudha et al., 2020). These objectives are essentially used as a methodology to discover and institute Maqasid Al-Dhoruriyyah (Yusob, Salleh, Haron, Makhtar, Asari, \& Jamil, 2015). Therefore, the role of Maqasid Al-Shariah in protecting people's life, property, health, religion, and dignity can never be underestimated (Auda, 2008). Maqasid Al-Shariah can play an exceptional role in both formulations of national and foreign policy, particularly in Islamic states.

Moreover, Maqasid Al-Shariah can guide the foreign policy of Islamic countries whose aim is to maintain Islamic principles in the national and international policy-making process. This is because the international conventional treaty may not be exclusively compatible with Shariah as envisioned by Islamic governments. In this regard, Maqasid Al-Syariah can be applied as a parameter in the international treaty-making process (Salleh et al., 2016). For instance, the objectives of Maqasid Al-Shariah can be properly utilized to bridge some weaknesses discovered in the conventional treaties on human rights. 


\section{Findings}

\section{Maqasid Al-Shariah and the Conventional Treaty}

According to the United Nations report (2015) entitled "Universal Declaration of Human Rights", States Parties shall respect the child's right to freedom of thought, conscience, and religion (Right of the Child, Part 1, Article 14, Paragraph 1). Everyone has the right to freedom of thought, conscience, and religion; this right includes freedom to change his religion or belief (Article 18). Additionally, States Parties that recognize and/or permit the system of adoption shall ensure that the best interests of the child shall be the paramount consideration (Right of the Child, Part 1, Article 2). These articles show that while the United Nations International Treaty maintained that a child has freedom of religion and "this right includes freedom to change his religion or belief", Maqasid Al-Shariah emphasizes that it is not permissible for a Muslim to forsake his religion and separate from the community (Sumbulah \& Purnomo, 2017). In this regard, the Messenger of Allah (peace and blessings of Allah be upon him) said, "It is not permissible to spill the blood of a Muslim except in three [instances]: the married person who commits adultery, a life for a life, and the one who forsakes his religion and separates from the community." (Al-Bukhari,1978).

Moreover. while the conventional treaty states that the child's right to freedom of association, Maqasid Al-Shariah shows that parents should have control over their children (Kusrin, Hamjah, \& Sham, 2015). Besides, the conventional treaty considers parents' control over their children as a form of interference and attacks. In this regard, the treaty states, "The child has the right to the protection of the law against such interference or attacks (Right of the Child, Part 1, Article 16, Paragraph 2). The interest of the child is paramount under the conventional law, which assumed that "the best interests of the child shall be the paramount consideration" (Right of the Child, Part 1, Article 2). To situate the position of Maqasid AlShariah concerning the international treaty, Islamic states must re-examine the aforementioned provisions. These issues have been discussed and thoroughly analyzed under Maqasid Al-Shariah. According to the objectives of Maqasid Al-Shariah, parents play a significant role in the better upbringing of a child. Children should be counseled and remain under their parents' care and supervision based on the following Hadith (Prophetic tradition). Obey your parents. If they command you to abandon your worldly possessions, then leave them for them. Do not contend with those in power, even if you think that you are in the right. Do not run away from the army when it advances, even if you are killed while your companions run away. Spend on your wife out of your means. Do not raise a stick against your wife. Cause your family to fear Allah, the Almighty and Exalted (Al-Albani, 1997).

Additionally, the Messenger of Allah (peace and blessings of Allah be upon him) said, "(Of the) major sins are: to ascribe partners to Allah, disobey parents, murder someone, and to take a false oath (intentionally)". (Al-Bukhari,1978). Allah (SWT) also says in Surah Al-Ahzab "Call them by (the names of) their fathers, that is more just with Allah". (Quran 33:5).

\section{Conclusion}

This study explored how Maqasid Al-Shairah can be applied in the foreign policy of Islamic states. According to the findings, the objectives of Islamic law can play a significant role in the foreign policy of Islamic states through the protection of people's life, property, health, religion, and dignity. Additionally, Maqasid Al-Shariah can be successfully incorporated in the foreign policy-making process of Islamic states, particularly where international treaties neglect or contradict the principles of Islamic law. These findings indicate that Maqasid AlShariah can be applicable as a parameter in an international treaty. 
Governments of Islamic countries should consider Maqasid Al-Shariah at both national and international levels. This consideration will serve as a milestone for strengthening the international relations of Islamic countries. Besides, the concerned authorities should understand why the application of Maqasid Al-Shariah is crucial, particularly for the foreign policy of Islamic states. It was envisaged that this study would be beneficial, particularly to Islamic countries, by providing information that can be useful in their foreign policy formulation. Also, this study adds to the previous studies by focusing mainly on the application of Maqasid Al-Shariah in the foreign policy of Islamic states. However, this study is limited to document analysis; hence, further studies may use interviews and document analysis to provide more detailed information.

\section{References}

Ahmed, J. (2019). The Theoretical Significance of Foreign Policy in International Relations-An Analyses. Journal of Critical Reviews, 7(2), 787-797.

DOI: http://dx.doi.org/10.31838/jcr.07.02.144

Al-Albani, M. N. (1997). Shahih al-Adab al-Mufrad. Riyadh: Maktabah Al-Dalil.

Al-Bukhari, M. (1978). Sahih Al-Bukhari. Riyadh: Maktabah Al-Dalil.

Al-Rodiman, A. (2013). The application of Shariah and international human rights law in Saudi Arabia (Doctoral dissertation). Brunel University, London.

Anceschi, L. (2010). Integrating domestic politics and foreign policy making: the cases of Turkmenistan and Uzbekistan. Central Asian Survey, 29(2), 143-158. doi: 10.1080/02634937.2010.498231

Auda, J. (2008). Maqasid Al-Shari'ah as a philosophy of Islamic Law: A System Approach. Washington: International Institute of Islamic Thought.

Bowen, G. A. (2009). Document analysis as a qualitative research method. Qualitative Research Journal, 9(2), 27-40. doi:10.3316/QRJ0902027

Cerny, P. G. (1996). Globalization and other stories: The search for a new paradigm for international relations. International Journal,51(4), 617-637. doi: 10.1177/002070209605100402

Dusuki, A. W. (2009). Shariah parameters on Islamic foreign exchange swap as hedging mechanism in Islamic finance. ISRA International Journal of Islamic Finance, 1(1), 7799.

Dusuki, A. W., \& Abozaid, A. (2007). A critical appraisal on the challenges of realizing Maqasid Al-Shariah in Islamic banking and finance. International Journal of Economics, Management, and Accounting, 15(2), 144-165.

Dusuki, A. W., \& Bouheraoua, S. (2011). The framework of Maqasid al-Shari'ah and its implication for Islamic finance. ICR Journal, 2(2), 316-336.

Fisol, W. N. M., Radzi, N. Z. M., \& Othman, Y. (2017). The engineering of Islamic legal opinion (ljtihad) on the Maqasid Al-Shariah development in the assessment of Islamic financial products. International Journal of Academic Research in Business and Social Sciences, 7(4), 945-956.doi: 10.6007/IJARBSS/v7-i4/2904

Gindarsah, I. (2012). Democracy and foreign policy-making in Indonesia: A case study of the Iranian nuclear issue, 2007-08. Contemporary Southeast Asia: A Journal of International and Strategic Affairs, 34(3), 416-437.

Hall, P. A., \& Soskice, D. (2003). Varieties of capitalism and institutional complementarities. In R. Franzese, P., Mooslechner, \& M. Schiirz (eds). Institutional Conflicts and Complementarities (pp. 43-76). New York: Springer. 
Hill, C. (2003). What is to be done? Foreign policy as a site for political action. International Affairs, 79(2), 233-255.doi: 10.1111/1468-2346.00306

Johnston, D. L. (2002). The human khilāfa: A growing overlap of reformism and Islamism on human rights discourse?. Islamochristiana, (28), 35-53.

Kamali, M. H. (1998). Principles of Islamic Jurisprudence. Kuala Lumpur: Ilmiah Publisher.

Karczewska, A., \& Magdalena, B. (2015). Public relations in the management of a modern enterprise. Retrieved from: http://real.mtak.hu/24730/1/ICoM_2015-paper042.pdf

Kohona, P. T. (2002). United Nations Treaty Collection-A Legal Framework for a Better World. Sri Lanka J. Int'I L., 14(1), 165-176.

Kusrin, Z. M., Hamjah, S. H., \& Sham, F. M. (2015). Muslim father's rights in determining his minor child's conversion to Islam in Malaysia. European Journal of Social Science Education and Research, 2(3), 15-21.doi: 10.26417/ejser.v4i1.p15-21

Laldin, A. (2014). Role of Shariah research in developing Islamic finance (Paper presentation). The $6^{\text {th }}$ Foundation of Islamic Conference, Durham University, United Kingdom.

Mandaville, P., \& Hamid, S. (2018). Islam as statecraft: How governments use religion in foreign policy. Washington, DC: Brookings.

Meyerhof, M. (1948). 'Alī al-Bayhaqī's Tatimmat Siwān al-Hikma: A Biographical Work on Learned Men of the Islam. Osiris, 8(1), 122-217.doi: 10.1086/368514? journalCode $=$ Osiris

Mohd, A. T., Yunus, A. M., Hassan, I. (2020). Ideology, Communication, and Response to Terrorism: A Sharia-based Perspective. International Journal of Academic Research in Business and Social Sciences, 10(3), 124-130.doi: doi:10.6007/IJARBSS/v10-i3/7029

Nadler, A., \& Saguy, T. (2004). Reconciliation between nations: Overcoming emotional deterrents to ending conflicts between groups. The psychology of diplomacy, 1(1), 2946.doi: 10.1.1.585.1499\&rep=rep1\&type=pdf

Putnam, R. D. (1988). Diplomacy and domestic politics: the logic of two-level games. International Organization, 42(3), 427-460.

Rani, F. A., Fikri, F., \& Mahfud, M. (2020). Islam and National Law: A Formal Legal Review on Sharia Laws in Aceh. Al-Risalah, 20(1), 47-57.

Salleh, M. A., Mohamed, A. M. T., Yusob, M. L. M., \& Yazid, F. A. M. (2016, December). Maqasid Al-Shariah as a Parameter in International Treaty (paper presentation). International Conference on Ethics in Governance. Amsterdam. Doi: 10.2991/iconeg16.2017.40

Sumbulah, U., \& Purnomo, A. (2017). Muslim Debates on Riddah and Freedom of Religion. Medwell Journals, 12(12), 2299-2307.

Tarasofsky, R. G. (2002). Recent developments in international treaties relating to forests. Policy Trend Report, 1(2), 143-149.

Thomas, D. C., \& Klare, M. T. (Eds). (1989). Peace and world order studies: A curriculum guide. Montrouge: John Libbey Eurotext.

United Nations (2015). Universal Declaration of Human Rights. Retrieved from: https://www.un.org/en/udhrbook/pdf/udhr_booklet_en_web.pdf

United Nations (1969). Vienna Convention on the Law of Treaties https://legal.un.org/ilc/texts/instruments/english/conventions/1_1_1969.pdf

Warner, C. M., \& Walker, S. G. (2011). Thinking about the role of religion in foreign policy: A framework for analysis. Foreign Policy Analysis, 7(1), 113-135.doi: 10.1111/j.17438594.2010.00125.x 
Wicaksana, I. G. W. (2019). The family state: a non-realist approach to understanding Indonesia's foreign policy. Asian Journal of Political Science, 27(3), 308-328.doi: 10.1080/02185377.2019.1686997

Witro, D. (2020). Ulama and Umara in Government of Indonesia: a Review Relations of Religion and State. Madania: Jurnal Kajian Keislaman, 24(2), 135-144.

Yudha, A. T. R. C., Ryandono, M. N. H., Rijal, A., \& Wijayanti, I. (2020). Financing model to develop local commodity business of East Java in Maqashid Syariah perspective. Test Engineering and Management, 3(3), 3590-3595.

Yusob, M. L., Salleh, M. A., Haron, A. S., Makhtar, M., Asari, K. N., \& Jamil, L. S. M. (2015). Maqasid al-Shariah as a Parameter for Islamic Countries in Screening International Treaties Before Ratification: An Analysis. Pertanika Journal of Social Sciences \& Humanities, 23(4), 19-225 